\title{
Financial Options For Mortgagors In A Declining Economic Market
}

Benjamin A. Neil, Towson University, USA

Janice J. Neil, Highland Title Company, USA

\begin{abstract}
Certainly, the current economic situation has drawn the focus of a large portion of the country to the lending industry and housing market. As lenders change their lending requirements in response to the credit crunch and pundits propose reforms designed to avoid future problems, part of this focus and momentum should be on the plight of the mortgagor's in this country. This article will examine the varying options currently available to mortgagors who are in difficult financial circumstances. Providing various alternatives, each of which falls short of achieving their ideal goals.
\end{abstract}

Keywords: Mortgage, refinance, reinstatement, repayment plan, forbearance, loan modification, short sale, deed in lieu, foreclosure and bankruptcy

\section{INTRODUCTION}

$\mathrm{t}$ is important to understand the plight of the American homeowner and what it affects - homeownership. According to the United States Census (Census), the homeownership rate in this country was at $67.8 \%$ as of April 28, 2008, and has remained at 62\% to 69\% over the past 40 years (U.S. Census Bureau, Homeownership Rates for the U.S. and Regions: 1965 to Present, April 28, 2008). In fact, according to a 1995 report by the United States department of Housing and Urban Development (HUD), home equity is the largest wealth source for American households, and homeowners, on average, hold $60 \%$ of their wealth in the equity of their home (U.S. Department of Housing and Urban Development, Homeownership and Its Benefits, Urban Policy Brief, Number 2 (August, 1995).

In fact, in 2000, the Census reported that equity in a household's own home constituted $32.3 \%$ of total household net worth (Shawna Orzechowski \& Peter Sepielli, U.S. Net Worth and Asset Ownership of Households: 1998 to 2000). This is significant considering that only two-thirds of Americans even own their own homes, yet it constitutes the largest single asset that homeowners own.

By contrast, the survey indicates that in that same year, stocks and mutual funds constituted only $15.6 \%$ of household net worth. (Orzechowski \& Sepielli, supra). Furthermore, a full two-thirds of single unit residential properties nationwide are secured by a mortgage (See U.S. Census Bureau, Residential Finance Survey - Detailed Regional Tables: 2001, revised December 7, 2005 showing that 37,968 of a total of 56,960 single housing units surveyed were mortgaged).

Taken together, these statistics mean that: 1) the majority of households in this country hold the equity in their homes as their primary asset, 2) equity constitutes the most significant portion of the average household's net worth, and 3) two-thirds of all household equity could be foreclosed upon. It is this wealth that must be protected.

\section{CURRENT OPTIONS AVAILABLE}

As the economic situation continues to change in America, more and more homeowner mortgagor's are finding themselves falling behind in their mortgage payments. Many times as a result of factors beyond their control. Usually, it falls into one of several different categories. First, they took on too much mortgage debt when 
they purchased a large home or they took a cash-out refinance. Second, they ran into unexpected financial hardships, either through loss of a job, injury, sickness or loss of a spouse. And third, they may have had their monthly mortgage payment adjust, as a result of the interest change on their ARM (adjustable rate mortgage) or an increase in their escrow payment. Due to an increase in their annual property taxes which are due to their municipality. All resulting in the sad fact that they can no longer afford to make their monthly mortgage payment.

When this happens, they usually accept the fact that their home will be sold at foreclosure. However, this is not necessarily the case, nor should it be. In fact, the homeowners have ten (10) separate and distinct avenues to pursue during these troubling times. This article will explore all ten of these options. They are as follows:

1. Refinance

2. Reinstatement

3. Repayment plan

4. Forbearance

5. Loan Modification

6. Selling your home

7. Short sale

8. Deed in Lieu

9. Foreclosure

10. Bankruptcy

\section{REFINANCE}

Refinance of home loans has become an increasingly popular and simple solution to his potential disaster. You can refinance completely and essentially have a whole new loan with better rates and a more manageable payment or you can take your existing loan and renegotiate your payments so that they fit your current budgetary needs.

If you have a pretty good credit rating and are still relatively stable financially then a refinance is probably your best option. (Jon Higgins, Ezine@ @rticles, March 28, 2009)

Refinancing is not an admittance of failure. It is also not a sign of desperation. A refinance is working with the problem or situation, and trying to make sure that the foundation where you have built your lives as a family will not be taken away from you. It's good business sense to pay less whenever possible, without compromising on everything, of course.

This means that your house is worth fighting for because it is a sound investment, and will serve you well when you most need it. Also, the fact that you have already invested in the property counts for a lot because if you allow your house to be foreclosed, you lose everything - the house, your self-esteem, all the previous payments made, and an uncertain future.

Looking for a mortgage broker to work with for your refinancing plans will take more than just one try. You should canvass for the best deals and person to work with because you will because you will be stuck with this plan for the term of your loan.(Greg J. Thompson, Ezine@ rticles,May 30, 2009)

Foreclosure is a scary situation many homeowners across the nation are currently facing. Especially those who bought homes during the booming real estate market and financed their purchase with an adjustable rate mortgage (ARM). Many of these mortgages are resetting to a much higher rate than the homeowners can afford. There are dozens of options for homeowners facing foreclosure and the easiest solution is refinancing. It is important to note that there will be costs associated with a foreclosure refinance.

Some lenders offer a no cost mortgage. With this type of mortgage, a borrower can avoid adding fees to their existing mortgage or paying closing costs with cash by agreeing to a higher interest rate. If you choose this option, it is important to make sure the overall monthly payment is an amount you can afford. 
However, when facing foreclosure, refinancing to a fixed rate that is slightly higher than your introductory rate is far better than losing your home, as long as you are financially able to make the slightly larger monthly payment. (Elizabeth Myrick, eHome Mortgages, 2009.)

\section{REINSTATEMENT}

If the reason you missed payments was temporary and it has been resolved, then you have the option to reinstate your mortgage right up until the bank sale.

In order to reinstate a mortgage, you must pay all missed payments, late fees, and legal fees that are due up until the date that the loan is reinstated. You request this amount from the mortgage company in the form of a reinstatement letter. This letter will typically expire after 30 days since the amount owed is time sensitive.

A simple reinstatement will require a one time payment of all delinquent funds in full. Once you make this payment, the mortgage is reinstated and you are free to make payments as you have before. (John Jones, John Jones $\underline{\text { Real Estate LLC, , 2009) }}$

The reinstatement amount is the total amount that is past due including late fees and attorney costs. This amount is what is required to bring your mortgage current. Because of your financial circumstances in the past, you may be facing a sizable amount of past due fees, including back payments, late fees and legal expenses. If you are able to pay the total in full to bring your payments to current status by a specific date, you may be eligible for a reinstatement plan. A reinstatement will offer you the quickest method for resolving your mortgage foreclosure. With your foreclosure resolved you can enjoy the security of your home. (residual-rewards.com,2009)

\section{REPAYMENT}

For homeowners, it's a nightmare scenario: You lose a job or fall seriously ill. You no longer have the money to pay the mortgage. More than half of all homeowners who fall behind on payments on loans are owned or insured by the three largest players in the mortgage market, and they are being offered financial rescue plans designed to save them from the horrors of foreclosure.

The study, co-authored by Richard K. Green, a George Washington University professor, and Amy Crews Cutts, deputy chief economist for giant Freddie Mac, examines the extent and effectiveness of these mortgage life saver plans, known as "loss-mitigation" techniques. The good news: They are, more than ever before, frequently offered to borrowers in trouble. And they really work. (Kenneth R. Harney, The Washington Post, Saturday, August 14, 2004).

Barely a decade ago, according to the study, most homeowners who missed two or more payments on their loans were treated as goners, heading for inevitable foreclosure. Only a small percentage of them were contacted by their lenders or loan servicers with offers of alternative, home-saving courses of action.

Today, by contrast, more than half of all seriously delinquent borrowers with loans owned or insured by the biggest mortgage players - Fannie Mae, Freddie Mac and the Federal Housing Administration (FHA) - are contacted, evaluated and offered repayment or "workout" options. Even more significant: Borrowers who agree to enter a formal repayment plan are 80 percent less likely to lose their homes than those who do not. Even among lower income borrowers, who have a tougher time pulling out of financial crises, 68 percent of repayment plan participants save their homes.

According to the study by Green and Crews Cutts, loans that go to foreclosure cost lenders and investors nearly $\$ 60,000$ on average in lost interest, property management fees, legal bills and resale commissions. Foreclosure is a sinkhole not only for homeowners, but also for their lenders.

Curing a foreclosure is a little like curing cancer - the sooner you catch it, the better your chance of survival. (Michael D. Larson, Bankrate.com,July 18, 2003). Solving foreclosures is what companies want to do 
these days, according to lending experts Fannie Mae, Freddie Mac and the mortgage servicers. "Servicers should be solicitous at every step of the process to try to help the borrower stay in the home," says Danny Smith, manager of loss mitigation at Fannie Mae. "The sooner there is a connection there between the two of them to work something out on the loan, the more likely the borrower is to stay in the home."

\section{FORBEARANCE}

Forbearance is when a lender agrees to let you delay your payments to them for a short period of time. That doesn't mean the lender has forgiven the debt but just allows you to pay what you owe at a later date.

Forbearance can be an option for someone that is experiencing temporary financial difficulty. If a borrower is unable to pay off his or her loan, the lender may initiate foreclosure proceedings, which allow the lender to seize the borrower's property. The lender may agree to delay foreclosure proceedings if he or she believes that the borrower will eventually be able to catch up on the payments due.

You sign a forbearance agreement that states the lender will require you to pay the amount you owe at a later date. This is a much better option than going into mortgage foreclosure. (Gary Gresham, Ezine@ @rticles, "Can Forbearance Benefit You?", December 10, 2005)

Under the forbearance agreement, you are still responsible for interest as it accrues and any unpaid interest is added to your principal balance. That means that you will pay interest on a higher balance when you do resume your payments.

Lenders may consider forbearance when you can show that funds from a bonus, tax refund, or other source will let you bring the mortgage current at a specific time in the future. They will also consider this an option if the borrowers financial problems are behind them and they can now pay the mortgage. (K. Patrice Williams, "Forbearance Agreements to Avoid Foreclosure", Articlesbase, July 26, 2008)

One final word of caution in this regard is that a forbearance will be granted for one year. After it is served, the borrower continues with the usual payment. Hopefully, he has recovered from his previous financial constraints.

\section{MODIFICATION}

A home loan modification, granted only upon the existing lenders approval, permanently reworks some of the terms of an existing mortgage in order to lower monthly payments and make the loan more affordable to the homeowner. The strategy is typically designed for homeowners struggling to pay their mortgagee, not for those who can pay their mortgage or are eligible for a refinanced loan.

The mortgage modification method of relief is at the top of the list of weapons used in the fight to stop foreclosures because struggling homeowners typically can't qualify for a refinanced mortgage.

Modifications are generally lender fee-free and involve the lender or loan holder lowering the interest rate and/or changing an adjustable rate mortgage (ARM) to a fixed rate mortgage with a 30 - year term. (Broderick Perkins, "Mortgage Modification Meltdown”, consumeraffairs.com,, December 23, 2008)

Mortgage servicers have put nearly $9 \%$ of delinquent borrowers into trial modifications under the Obama foreclosure prevention plan, according to the Treasury Department. That translates into 235,247 loans that were at least 60 days delinquent at the 38 loan servicing firms participating in the program. Institutions have extended modification offers to 406,542 troubled borrowers, or $15 \%$ of those behind in payments. Tami Luhby, "9\% of late home loans get help", (CNNMONEY August 4, 2009).

The Obama administration reports that 200,000 mortgages have been modified since March, which is actually a small number relative to foreclosures. (Richard A. Posner, The Atlantic Monthly July 28, 2009) 
The Washington Post found in a very large sample of residential mortgages that only 3 percent of seriously delinquent borrowers received a modification of their mortgage "that reduced their monthly payments in the year after they got into trouble" and only 8 percent of those borrowers received any kind of modification.( Renae Merle, Washington Post, July 28, 2009).

In a scathing indictment of loan modifications efforts, the National Association of Consumer Bankruptcy Attorneys (NACBA) says:

- When loan modifications are written, fewer than one in ten of them result in a reduced principal loan balance.

- More than half of loan modifications roll unpaid interest and fees into larger, more drawn-out debt on the back end of the mortgage.

- $\quad$ Only 35 percent of mortgage modifications reduce monthly payment burdens for homeowners.

- $\quad$ A full 40 percent of loan modifications are packaged with increased payments.

Recently, Credit Suisse was prompted to forecast 8.1 million U.S. mortgage foreclosures in the next four years. That forecast was up sharply from the 2 to 6 million foreclosures previously forecast by a variety of industry experts.

In its first report in February, 2008, the State Foreclosure Prevention Working Group, comprised of Attorney Generals and state banking departments, reported that the vast majority, 70 percent of seriously delinquent borrowers were not on track for any loss mitigation option.

\section{SELLING YOUR HOME}

Not all homes that go into default go all the way through foreclosure. Many sell before the notice of default is finalized. Sometimes sellers in default and buyers enter into a profitable transaction for both parties. If you have equity in your house, you may sell it and cure the foreclosure. Unfortunately, many sellers believe that they have to sell much faster than they actually have to and they end up taking the first offer that comes along.

If you do not believe you will be able to cure your loan and cure the default, a private sale of the property will enable you to meet your obligations and receive any equity you may have built up. Most private sales are for more than the amount owing on the loan. You may sell the property to a buyer who gets his or her own financing and pays off you loan or to a buyer who will assume your responsibility for the loan. (U.S. Department of Veterans Affairs, February 24, 2009).

Nearby homes will feel the effect, which could pull the market value of a newly purchased sale even lower. Fixing up the home or improving it and the amount of profit can be even greater. Besides, many distressed homes fall into disarray and require repairs. Even though repairs before resale can boost the bottom-line profit, not all repairs and improvements return $100 \%$ of an investment.

But it's not for the faint of heart. Distressed home sales are often complicated and sellers have rights when in foreclosure. Both sellers and buyers should seek legal advice before entering into such a contract. (Elizabeth Weintraub, About.com, 2009)

\section{SHORT SALE}

Homeowners who are "underwater" in their homes - owing more on their mortgage than the value of the home - can turn to a short sale to avoid foreclosure. Simply put, a short sale is accomplished when the homeowners sell the property and their lender agrees to accept the sale price as payment on the loan. ( Michele Lerner, The Washington Times, July 31, 2009, ). However, a strict policy of lenders is that the homeowner may not receive any proceeds from the sale of the property if the lender agrees to the short sale. ( Dave Dinkel, Articlebase, August 18, 2008). 
A short sale means a sale that falls short of the amount owed on the mortgage. They happen only when the seller can't come up with the cash to pay off the difference. Most important, though, is that they can happen only when the lender agrees to accept the shrunken payoff. (Elizabeth Razzi ,The Washington Post, June 15, 2008, )

Unfortunately, many homeowners are watching potential buyers walk away as months pass while they deal with lenders' lengthy delays, lost documents and unreturned calls, according to the National Association of Realtors (NAR). Not all the snafus are the lenders' fault, inexperienced real estate agents who fail to turn in complete paperwork also are causing holdups, as are severely underpriced homes. (Stephanie Arnour , USA Today, Aug., 5, 2009).

Just $23 \%$ of short-sale offers that homeowners receive from potential buyers actually close, according to a February study of 1,300 real estate agents by Campbell Communications. More than $90 \%$ of agents cited slow a response from the lender as the reason short sales were lost. "The delays are quite extensive and a real problem. It's a serious issue" says Mark Zandi of Moody's Economy.com. "You're seeing a lot of short sales go bust, and it's contributing to the crisis because it's one of the reasons foreclosures continue to mount."

Short sales once were extremely rare. But now, with unemployment climbing and home values down, more homeowners are pursuing short sales when they can't afford their mortgage. About $11 \%$ of all sales in June are such short sales, according to NAR. "About half of the short sales never close. We see it as a big lost opportunity, and we need to improve the rate we close them," says David Sunlin, vice president in charge of short sales at Bank of America.

Uncompleted short sales that go to foreclosure are costlier for lenders and homeowners. For lenders, a short sale may save as much as $30 \%$ of the expense incurred by going to foreclosure. For homeowners, a foreclosure wreaks longer - lasting damage to their credit records. A homeowner who has gone through a short sale typically can get a new home loan in one to three years, according to NAR. A foreclosure usually means it takes seven.

But mortgage executives say they are now working more cooperatively on short sales, and proposed changes in the industry could increase the number of these transactions. According to Andre L. Mitchell, the executive vice president of the Lynx Mortgage Bank in Westbury, N.Y. The Treasury department recently said that it would increase incentives for lenders to work out short sales when borrowers fail to keep pace with their loan payments. The department did not release details about the incentives. Mr. Mitchell of Lynx says short sales are often the next approach, even for homeowners considering a new loan to save the home. "It's gotten to the point where people understand that sometimes you have to start over", he said. "A loan modification might help you in the short term, but sometimes what people need to do is get out completely."

Apparently, more and more lenders are willing to make accommodations to avoid taking the property back. Banks hate to take over homes, especially in a declining market, so you shouldn't underestimate the willingness of a bank to make concessions. (Dean Foust ,Businessweek.com, March 5, 2009 ).

\section{Short Sale Tips for Sellers}

- $\quad$ Contact your lender as soon as you recognize you will have a problem paying your mortgage.

- $\quad$ Continue to pay your mortgage as long as you can; even partial payments are better than no payment at all.

- Make sure you and your listing agent have all the necessary documentation - including a hardship letter, financial documents, authorization from the bank and an exclusive right-to-sell agreement.

- $\quad$ Be very specific and clear in your hardship letter, explaining, with numbers, why you need a short sale

- Work with a realtor who can do an accurate market analysis and price your home according to its true market value.

- Work with an attorney who can make sure that the title transfer and release of liens is handled appropriately.

- $\quad$ Make sure you understand everything you sign; particularly important is understanding your future obligations (if any) toward the unpaid debt.

- $\quad$ Consult a tax attorney to be sure you understand the tax obligations of a short sale. 


\section{Short Sale Tips for Buyers}

- Be patient and flexible with the settlement date; short sales can take from 45 to 60 days or more.

- $\quad$ Have an alternative plan in place in case the short sale is never approved.

- $\quad$ Short sales don't make sense to buyers in temporary housing, which must be vacated by a certain date.

- Homes in better condition are more likely to receive Federal Housing Administration appraisal approval.

- $\quad$ Agents need to consistently communicate with buyers, sellers and the lender in a short sale to make sure everyone can come to an agreement on the terms.

- Work closely with lawyers who have good access and relations with the lender in order to expedite a short sale, especially the title transfer and the release of any liens on the property. The last thing a first-time buyer needs is to deal with the unpaid debts of the previous owner.

- Make sure to get an inspection. Homeowners who have been struggling to pay their bills are likely to have deferred important maintenance on their home. While adding a fresh coat of paint is a minor job for firsttime homeowners, repairing the roof or replacing the furnace are expensive propositions that may be a budget breaker for the household. A home inspector can evaluate the systems and appliances and provide an estimate of when things might need to be replaced.

- $\quad$ Pay careful attention to the details of the contract. When sellers are in financial distress there is a greater likelihood of items being removed from the home or damage occurring during the move (Michele Lerner, The Washington Times, July 31, 2009).

\section{DEED IN LIEU}

This option is sometimes referred to as a "friendly foreclosure", since you essentially give the deed to your property back to the bank. This action may prevent the lender from having to go through a lengthy foreclosure process; in exchange the bank will sometimes forego its rights to a deficiency judgment. The mortgage company agrees to take the deed back in exchange for the property and it typically has no further recourse.

This solution only works in cases where there is one mortgage and there are no liens (or very small liens) on the property or in rare cases where the first mortgage holder is willing to negotiate with junior mortgage holders. This happens infrequently and was previously unheard of before the current mortgage crisis.

If you have equity in your house, this is not a good option since you will give up any right to the property and any equity when using deed-in-lieu as a solution.

Lenders don't always like to take a deed in lieu of foreclosure even thought it may save them money and time. There is a downside, which, depending on the situation, could make foreclosure a better alternative. First, if a lender is considering a deed-in-lieu, he needs to look at the property, just as a buyer of the real estate would look at the property. The lender has to do what is called "due diligence". This means that he is responsible for looking at both the physical condition of the property and the legal condition of its title.

When reviewing the physical condition of the property, he will look at whether the property has been damaged, and whether there are environmental concerns. Also, the lender will look at the current state of the title. Have any liens, like mechanic's liens or second mortgage /deeds of trust been recorded on the public records since the lender made this loan?( Elizabeth Truglio, "Deed-in-lieu of foreclosure: Why not" Examiner.com, February 3, 2009)

You do not need to be in foreclosure to do a deed in lieu. But lenders won't pay attention to you in many cases unless you are in foreclosure or at least are delinquent. Most of the time, unless you negotiate otherwise, a deed in lieu is reported as a foreclosure.

The mortgage company will insist that they can't do anything about this, but they can. They can report, ideally, "Paid-Satisfactory" but if they are unwilling to do this, "Paid-Settlement" is okay too. You don't want a foreclosure on your record. The lender can't do anything about a public record but they can change how they report 
your credit. Ask them about "unrated" or "RO", which is even better. The loss mitigation person may not know what this is but it is really nice because it removes any late payment reports and other derogatory information. (Richard Geller, "How to do a grant deed in lieu of foreclosure and keep a good credit score" American Chronicle, August 15, 2009)

The fact that you made a deed-in-lieu arrangement will most likely be picked up by credit reporting services. In the future, when applying for another loan for another property, the loan application will ask if you had prior defaults that resulted in a foreclosure or a deed-in-lieu. As far as your credit rating is concerned, they will often be considered the same thing.

The deed-in-lieu however, may be better than a full foreclosure process because it shows that you are willing to work with the lender.( Elizabeth Truglio ," Deed-in-lieu of foreclosure: Why not") Examiner.com, February 3, 2009.

Deed-in-lieu agreements may only be accepted if a mortgagor is able to substantiate their incapacity to finance their mortgage payments. This requires completion of a financial package and the provision of a copy of the borrower's recent real estate listing.( Bobby Presley, "Deed-in-lieu of Foreclosure Agreements Save Credit Rating", Articlebase, May 19, 2009)

However, if the value of the house on the market is bigger than the amount of money that was borrowed, it is advisable to sell the house, instead of taking action for a deed-in-lieu of foreclosure. There is a clear advantage for choosing a deed-in-lieu of foreclosure as well, as a settlement. The lender will receive the title to the property before the foreclosure procedures end. This means a lot of time saving for the borrower. Also, the bank has something to win, as well. Instead of spending big money on court fees, it settles the deal without the need for any legal action. ( Balva Rudick, "What does a deed in lieu of foreclosure mean?" Articleclick, August 19, 2008,)

Unfortunately, the homeowner is, or shortly will be, inundated by people trying to help with his foreclosure because he has become part of the public record and usually he is getting information from well-meaning but uninformed people. However, he will be set upon by professionals looking to sell him foreclosure services or take the equity from his home by buying his home very inexpensively.

For borrowers who have no other option to save their home and begin making timely payments again, a deed-in-lieu of foreclosure is often their last resort before abandoning the house altogether. Of course, this option is not for every homeowner. But then, a deed-in-lieu would certainly be better than just walking away. ( Nick Adama, "Deed in lieu - when to use it to stop foreclosure" Article Alley, April 8, 2009)

\section{FORECLOSURE}

The county's unemployment is overtaking subprime mortgages as the main driver of foreclosures, according to bankers and economists, threatening to send even higher the number of borrowers who will lose their homes and making the foreclosure crisis far more complicated to unwind. ( Renae Merle, "Jobless spike compounds foreclosure crisis", Washington Post, August 18, 2009)

Economists estimate that 1.8 million borrowers will lose their homes this year, up from 1.4 million last year, according to Moody's Economy.com. During the first three months of this year, the largest share of foreclosures shifted from sub-prime loans to prime loans, according to the Mortgage Bankers Association. The change to prime loans - traditionally considered safer - reflects the growing numbers of unemployed who are being caught up in the foreclosure process, economists say.

Last year, about 40 percent of borrowers who sought help at NeighborWorks, a large housing counseling group, cited unemployment or a cut as a primary reason for their delinquency. Now it is about 65 percent. The number citing a subprime loan fell significantly. 
Banks and government regulators are studying how to address the shifting nature of the crisis, which has been exacerbated by falling home prices. When the housing crisis began in 2007, the unemployment rate was about 4.6 percent. It hit 9.4 percent last month, and many economists expect it to reach 10 percent by the end of the year. (Renae Merle, "Jobless spike compounds foreclosure crisis", Washington Post August 18, 2009).

Homeowners stop making payments for a host of reasons. Few choose to go into foreclosure voluntarily. It's often an unpredictable result from one of the following:

- $\quad$ Laid-off, fired or quit job

- $\quad$ Inability to continue working due to medical conditions

- $\quad$ Excessive debt and mounting bill obligations

- $\quad$ Squabbles with co-owner or divorce

- Job transfer to another state (Elizabeth Weintraub , "Buying Foreclosures - How Foreclosures Work", About.com,)

Some claim that there will be a second wave of foreclosures, while others disagree. According to Sam Khater, senior economist with First American CoreLogic, "there is no second foreclosure wave coming. To say there is a second wave implies the (current) wave has receded. I don't see that the wave has receded."

The 90-day rate includes all outstanding first mortgages at least three months late but not yet foreclosed. The foreclosure rate is just first mortgages with a notice of default or trustee's sale filing. If you look at the 90-day rate it has been heading straight up - it has not receded. Khater said the foreclosure rate and REO rates have been impacted by government tinkering in the market. He said federal and state efforts have mostly delayed foreclosures, preventing few. In Khater's view it shows "one giant wave". (Matthew Padilla, "Forecosure wave gathers momentum" Orange County Register, August 6, 2009).

These days, record-breaking foreclosure statistics are coming out with numbing frequency. But what happens to the thousands of families after their personal financial disaster is added to the mounting national count? Unfortunately, once a foreclosure is final, the financial and emotional upheavel is far from over. While there's considerable pain, most foreclosure victims will eventually become homeowners again, says Jay Zagorsky, a research scientist at Ohio State University.

Foreclosure is loosely defined as a lawsuit by the lender taken against the borrower. It essentially becomes a court-ordered sale of your house. You should know that lenders do not want to take your home. According to Freddie Mac, the average foreclosure costs lenders $\$ 60,000$.

If your home mortgage was FHA-insured, the lender must refer you to a housing counseling agency that has been approved by HUD. You will work with a counselor and the lender to work out a repayment plan to bring your home mortgage current or to sell your home.

If your home mortgage is not FHA-insured, FHASecure is a refinancing option that gives homeowners with non-FHA adjustable rate mortgages (ARMs) the ability to refinance into an FHA-insured mortgage. With FHASecure, the lender will not automatically disqualify you from refinancing because you are delinquent on the mortgage loan in question, and the lender may offer you a second mortgage to make up the difference between the current value of your property and the amount you still owe. FHASecure refinancing can help you lower your monthly payments and avoid default.

If you have options proposed to you that appear to be "too good to be true", they probably are. People are aware this is stressful a situation for you and may try to take advantage of you. Do not rush into any hasty decisions.

\section{BANKRUPTCY}

To most people, bankruptcy is a four-letter word. But when all else fails, declaring bankruptcy can be an honest and time-tested legal maneuver to save your house from foreclosure. 
If nothing else, filing for bankruptcy protection will buy you some breathing room, which is particularly important in "non-judicial" states where the clock on foreclosure starts as soon as your lender posts a notice that it intends to accelerate your note.

In "judicial" states like California, the process of repossessing a house can take as much as six months, "so you can really see it coming," said Reed Allmand, partner at Allmand \& Lee and author of "the Truth About Bankruptcy." But in Texas, a non-judicial state, the clock runs out in 30 days. So "once you are notified," the Dallas attorney said, "it's very difficult to negotiate a deal with your lender because there is not enough time." ( Lew Sichelman, "Bankruptcy is an option for homeowners trying to avoid foreclosure", latimes, July 12, 2009)

Under the law, there are two types of bankruptcies that apply to individuals, Chapter 7 and Chapter 13. A Chapter 7 proceeding involves the absolute liquidation of a debtor's property to pay off unsecured debt. A Chapter 7 liquidation is typically the choice for people with few assets, little income and lots of debt. Chapter 7 may also be the best option if you are simply ready to throw in the towel on your house.

The American Bar Association says 2 of every 3 households that file Chapter 13 don't complete the workout. If that happens, everything is liquidated. According to Craig Watts, public affairs director at FICO, the company that created the leading credit scoring formula, bankruptcy weighs more heavily because it typically involves more than one account, whereas foreclosure usually involves just your mortgage.

The current turmoil in the U.S. economy has been accompanied by an unprecedented joint increase in bankruptcy and foreclosure rates. In 2008, U.S. consumer bankruptcy filings increased by nearly 33 percent over the previous year, to a total of more than 1 million. During the same period, more than 2.3 million properties faced foreclosure, which represents an 81 percent increase over 2007 and a 225 increase over 2006. This twin-crisis of rising foreclosure and bankruptcy rates has been the most visible effect of the recent economic downturn on American households. (Theresa Kuchler and Johannes Stroebel, "Foreclosure and Bankruptcy - Policy Conclusions From the Current Crisis", Stanford Institute for Economic Policy Research, Stanford University, July, 2009)

Foreclosures have shown to further depress local house prices, lowering expectations of future house prices and setting off a downward spiral of further foreclosures. First American Core Logic's Negative Equity Report of March 4, 2009, shows that in California, there are more than 1.9 million borrowers that are "underwater" (United States: 8.3 million), of which 723,000 have a loan-to-value ratio of more than 125 percent.

In Maryland, more than 12 percent of borrowers were behind on their mortgages in the spring, a record number. The Mortgage Bankers Association stated that delinquencies are quickly increasing among prime mortgages - the sort given to people seen as good credit risks - as unemployment mounts. About 90,000 more Marylanders were out of work and looking for a job in June than was the case a year earlier, according to the Labor Department.

More than 130,000 borrowers in the state were at least one payment behind on their mortgages during the spring, according to the mortgage bankers' survey. That includes homeowners whose lenders had started foreclosure proceedings. Just over half of those borrowers were in prime loans. The rest had subprime mortgages or loans insured by the FHA or VA.

The number of borrowers in trouble increased 58 percent from a year ago, when the survey counted about 85,000 Marylander's in trouble. The trade group's survey of Maryland mortgages dates back to 1979. (Jamie Smith Hopkins), "Maryland borrowers behind on mortgages at record level", Baltimore Sun, August 20, 2009).

Even though you cannot get rid of your mortgage payments through bankruptcy, about one in five people who went through mandatory pre-bankruptcy credit counseling said they were doing so to avoid losing their homes to foreclosure, according to Consumer Credit Counseling Services of Greater Atlanta. From April through June, they counseled 50,385 people who planned to file. Each month, just over 20 percent said they were seeking bankruptcy protection to avoid foreclosure. According to the American Bankruptcy Institute, filing a bankruptcy petition creates 
an automatic stay against debt-collection efforts, which stops foreclosures - if only temporarily. If the owner doesn't continue to make payments, the foreclosure process can resume.

But relief from other debts could create enough room in the budget for a strapped homeowner to make mortgage payments.( Elizabeth Razzi "“Choosing Bankruptcy to Avoid Foreclosure", The Washington Post, August 6, 2009).

The FICO scoring formula regards both bankruptcy and foreclosure as serious delinquencies, but it is a bankruptcy that typically lowers a person's score by more points. That's because bankruptcy typically involves more than one account on your credit report, while foreclosure typically involves just one. (Lew Sichelman,"Rock and a hard place", marketWatch, June 18, 2009).

"It is this multiple impact that causes bankruptcy to produce a greater impact to the person's score," says Craig Watt, director of public affairs at FICO, formerly Fair Isaac Co. The good news is that your score will typically begin to recover from either form of delinquency after a couple of years, as long as there is recent evidence of good credit habits.

"As it ages," Watt says, "the foreclosure or bankruptcy information will gradually have less effect on the person's score until the credit reporting agency removes it from the credit report after seven years (10 years for Chapter 7 bankruptcy)." "Bankruptcy relief - which should apply to all borrowers - is a common sense solution." (Joe Keefe, "Bankruptcy Relief for Homeowners at Risk of Foreclosure" Huffington Post, April 26, 2009)

According to Ray Hooper, Education and Housing Director for the Consumer Credit Counseling Service of Greater Dallas, a non-profit agency that tries to help people facing foreclosure keep their homes. Before you accept that foreclosure is a foregone conclusion, consider trying to avoid it. (John Schoen, "Which is worse: foreclosure or bankruptcy?", MSNBC.com, Oct. 29, 2007).

\section{CONCLUSION}

Currently, this country is in the midst of what appears to be the beginning of a recession. (See Paul Krugman, "A Long Story", N.Y. Times A19 (Feb 8, 2008). Systemic of the problem, foreclosure and delinquency rates have increased staggeringly, with delinquency rates hitting the highest level in their twenty-two year recorded history (Marilyn Lewis," Home Prices Plummet to 2005 Levels”, MSN Money, Aug 28, 2008).

As the housing and credit bubbles burst, many pundits are questioning the extent and duration of problems on the horizon (See e.g. Krugman, supra noting past experience would suggest that the recession will last until 2010 and predicting a worse situation than the recessions of 1990 and 2001).

While commentators are divided as to the scope of the crisis, almost all agree that the near future is bleak and attributes the bursting of the credit and housing bubbles as the spark (See e.g. Krugman, supra).

\section{AUTHOR INFORMATION}

Benjamin A. Neil is an Associate Professor of Business Law and Legal Studies at Towson University, located in Baltimore, Maryland. He has published other works relating to real estate issues and has presented at numerous conferences. He can be contacted at bneil@ towson.edu

Janice J. Neil has practiced as an attorney, as well as a certified public accountant. She currently serves as the VicePresident for Highland Title Co. A residential settlement business located in Baltimore City, Maryland. 


\section{REFERENCES}

1. U.S. Census Bureau, Homeownership Rates for the U.S. and Regions: 1965 to Present, April 28, 2008.

2. U.S. Department of Housing and Urban Development, Homeownership and Its Benefits, Urban Policy Brief, Number 2 August, 1995.

3. Shawna Orzechowski \& Peter Sepielli, U.S. Net Worth and Asset Ownership of Households: 1998 to 2000.

4. See U.S. Census Bureau, Residential Finance Survey - Detailed Regional Tables: 2001 revised December 7, 2005.

5. Jon Higgins, Ezine @ rticles, March 28, 2009.

6. Greg J. Thompson, Ezine@ @ rticles, May 30, 2009.

7. Elizabeth Myrick, eHome Mortgages, 2009.

8. John Jones, John Jones Real Estate LLC, 2009.

9. residual-rewards.com,2009.

10. The Washington Post, , Saturday, August 14, 2004.

11. Michael D. Larson, Bankrate.com,July 18, 2003.

12. Gary Gresham, Ezine@rticles, “Can Forbearance Benefit You?”, December 10, 2005.

13. K. Patrice Williams, "Forbearance Agreements to Avoid Foreclosure", Articlesbase, July 26, 2008.

14. Broderick Perkins, "Mortgage Modification Meltdown", consumeraffairs.com,, December 23, 2008.

15. CNNMONEY August 4, 2009.

16. Richard A. Posner, The Atlantic Monthly July 28, 2009.

17. Renae Merle, Washington Post, July 28, 2009.

18. U.S. Department of Veterans Affairs, February 24, 2009.

19. Elizabeth Weintraub, About.com, 2009.

20. Michele Lerner, The Washington Times, July 31, 2009.

21. Dave Dinkel, Articlebase, August 18, 2008.

22. Elizabeth Razzi, The Washington Post, June 15, 2008.

23. Stephanie Arnour, USA Today, Aug., 5, 2009.

24. Dean Foust, Businessweek.com, March 5, 2009.

25. Michele Lerner, The Washington Times, July 31, 2009.

26. Elizabeth Truglio, "Deed-in-lieu of foreclosure: Why not" Examiner.com, February 3, 2009.

27. Richard Geller, "How to do a grant deed in lieu of foreclosure and keep a good credit score" American Chronicle, August 15, 2009.

28. Bobby Presley, "Deed-in-lieu of Foreclosure Agreements Save Credit Rating”, Articlebase, May 19, 2009.

29. Balva Rudick, "What does a deed in lieu of foreclosure mean?" Articleclick, August 19, 2008.

30. Nick Adama, "Deed in lieu - when to use it to stop foreclosure" Article Alley, April 8, 2009.

31. Renae Merle, "Jobless spike compounds foreclosure crisis", Washington Post, August 18, 2009.

32. Elizabeth Weintraub, "Buying Foreclosures - How Foreclosures Work", About.com.

33. Matthew Padilla, "Forecosure wave gathers momentum" Orange County Register, August 6, 2009.

34. Lew Sichelman, "Bankruptcy is an option for homeowners trying to avoid foreclosure", L A Times, July 12, 2009.

35. Theresa Kuchler and Johannes Stroebel, "Foreclosure and Bankruptcy - Policy Conclusions From the Current Crisis", Stanford Institute for Economic Policy Research, Stanford University, July, 2009.

36. Jamie Smith Hopkins, "Maryland borrowers behind on mortgages at record level", Baltimore Sun, August 20, 2009.

37. Elizabeth Razzi ,"Choosing Bankruptcy to Avoid Foreclosure”, The Washington Post, August 6, 2009.

38. Lew Sichelman, "Rock and a hard place", marketWatch, June 18, 2009.

39. Joe Keefe, "Bankruptcy Relief for Homeowners at Risk of Foreclosure" Huffington Post, April 26,2009.

40. John Schoen, "Which is worse: foreclosure or bankruptcy?", MSNBC.com, Oct. 29, 2007.

41. See Paul Krugman, "A Long Story”, N.Y. Times A19 (Feb 8, 2008.

42. Marilyn Lewis," Home Prices Plummet to 2005 Levels", MSN Money, Aug 28, 2008. 